\title{
The immediate effects of abrupt diet composition changes in young pigs
}

\author{
BY I. KYRIAZAKIS AND G. C. EMMANS \\ The Edinburgh School of Agriculture, West Mains Road, Edinburgh EH9 $3 J G$
}

(Received 29 December 1989 - Accepted 4 June 1990)

\begin{abstract}
Forty pigs (twenty males and twenty females) were weaned at 4 weeks of age into individual cages, and their weights and feed intakes measured daily. From weaning to $16 \mathrm{~kg}$ live weight they were given free access to a feed with either $134(\mathrm{~L})$ or $278(\mathrm{H}) \mathrm{g}$ crude protein (nitrogen $\times 6.25) / \mathrm{kg}$ fresh weight. During this period pigs on feed $L$ grew at a slower rate and converted feed less efficiently than pigs on feed $\mathrm{H}$. At $16 \mathrm{~kg}$ live weight they were introduced to a $6 \mathrm{~d}$ period of feeding when, on succesive days, they were given feeds $L, H, L, H, L$ and $H$ (if previously fed on $L$ ) or feeds $H, L, H, L, H$ and $L$ (if previously fed on $H$ ). For pigs previously given access to feed $L$ the live-weight gain was $1061 \mathrm{v} .575 \mathrm{~g} / \mathrm{d}$ on the days when $\mathrm{H}$ or $\mathrm{L}$ was given; the feed intake was $1078 \mathrm{v} .1027 \mathrm{~g} / \mathrm{d}$ respectively. For pigs previously given access to feed $\mathrm{H}$, the live-weight gain was $655 \mathrm{v} .610 \mathrm{~g} / \mathrm{d}$ and the feed intake $844 \mathrm{v} .1071 \mathrm{~g} / \mathrm{d}$ on the days when $H$ or $L$ were given. The interactions between the feed given previously and the feed given for the $3 \mathrm{~d}$ of the subsequent $6 \mathrm{~d}$ period were highly significant for both live-weight and feed intake. These rapid changes in feed intake and growth rate suggest that the metabolism of young pigs is extremely flexible, with a rapid rate of response to a change in the protein content of their feed.
\end{abstract}

Feed intake: Dietary protein: Pig

Pigs, like other domesticated species (e.g. sheep, Ranhorta \& Jordan, 1966; chickens, Kirschgessner et al. 1978), are able to control their protein intake in the long term. When given access to a feed marginally deficient in protein they increase their rate of feed intake and, hence, get fatter (Henry, 1985; Stamataris et al. 1986). Some preliminary evidence (Kyriazakis, 1989) suggests that there is also a short-term regulation of protein intake when pigs are offered low- and high-protein feeds on alternate days. The suggestion that pigs can respond rapidly to daily changes in the composition of their diet disagrees with the view that changes in the rate of feed intake, and consequently growth rate, take an appreciable time to be established (Vaughan et al. 1962; Waterlow \& Stephen, 1967). The objectives of the experiment reported here were first to examine the effects of daily abrupt changes in the protein content of the feed on both intake and growth rates of young pigs, and second to investigate how the composition of the feed given previously affects the magnitude of these responses.

\section{MATERIALS AND METHODS}

Forty Cotswold F1 Hybrid Large White $\times$ Landrace pigs (twenty entire males and twenty females), from seven litters, were individually caged in a controlled environment house. The pigs were moved immediately after weaning at 4 weeks of age when they had a mean liveweight of 6.82 (SD 1.01) kg. Half of them (equal numbers from the two sexes) were offered free and continuous access to feed $L$ and half to feed $H$.

The composition and chemical analysis of the two feeds are given in Table 1. Feed $\mathrm{L}$ contained $134 \mathrm{~g}$ crude protein (nitrogen $\times 6.25 ; \mathrm{CP}) / \mathrm{kg}$ and was based on oatflakes and milk substitute; in feed $\mathrm{H}$ some of the oatflakes were replaced by fishmeal and milk substitute, to give a CP content of $278 \mathrm{~g} / \mathrm{kg}$. Both feeds were calculated to have similar 
Table 1. The composition and chemical analysis of the two feeds used $(\mathrm{g} / \mathrm{kg}$ fresh feed)

\begin{tabular}{|c|c|c|}
\hline & \multicolumn{2}{|c|}{ Feed } \\
\hline & $\mathbf{L}$ & $\mathbf{H}$ \\
\hline \multicolumn{3}{|l|}{ Ingredients (g/kg) } \\
\hline Fishmeal & - & 225 \\
\hline Oatflakes & 727 & 347 \\
\hline Milk substitute & 185 & 350 \\
\hline Molasses & 50 & 50 \\
\hline $\begin{array}{l}\text { PT } 10 C \text { vitamin and } \\
\text { mineral supplement }\end{array}$ & 5 & 5 \\
\hline Vitamin E supplement & $7 \cdot 5$ & $10 \cdot 5$ \\
\hline Salt & $2 \cdot 5$ & $2 \cdot 5$ \\
\hline Dicalcium phosphate & 23 & 10 \\
\hline \multicolumn{3}{|l|}{ Component $(\mathrm{g} / \mathrm{kg})$} \\
\hline Digestible energy* (MJ/kg) & $15 \cdot 8$ & $17 \cdot 1$ \\
\hline Dry matter & 921 & 920 \\
\hline Crude protein (nitrogen $\times 6.25$ ) & 134 & 278 \\
\hline Diethyl ether extract & 79 & 80 \\
\hline Ash & 58 & 87 \\
\hline Crude fibre & 15 & 13 \\
\hline Gross energy $(\mathrm{MJ} / \mathrm{kg})$ & $17 \cdot 0$ & $17 \cdot 4$ \\
\hline
\end{tabular}

* Values calculated from feed tables.

digestible energy contents and to be abundant in minerals and vitamins. Feed $\mathrm{H}$, however, contained higher amounts of macrominerals in order to maintain suitable ratios relative to protein.

At a live weight of $16 \mathrm{~kg}$ the pigs were introduced to a $6 \mathrm{~d}$ period of feeding in which, on successive days, they were given feeds $L, H, L, H, L$ and $H$ (if previously fed on $L$ ) or feeds $\mathrm{H}, \mathrm{L}, \mathrm{H}, \mathrm{L}, \mathrm{H}$ and $\mathrm{L}$ (if previously fed on $\mathrm{H}$ ). The pigs were weighed on an electronic scale to the nearest $10 \mathrm{~g}$ and their daily feed refusal measured to the nearest $1 \mathrm{~g}$, between 08.30 and 09.30 hours each day, in the same order.

\section{RESULTS}

To exclude the effects of the post-weaning stress (which were variable between pigs) the analysis considered the live-weight gains and feed intake from $9 \mathrm{~kg}$ live weight. Pigs on the low-protein feed (L) took significantly more time to reach $16 \mathrm{~kg}$ live weight. From 9 to $16 \mathrm{~kg}$ live weight, for feeds $\mathrm{L}$ and $\mathrm{H}$ respectively, the weight gains were 386 and $591 \mathrm{~g} / \mathrm{d}$ (standard error of difference (SED) $17 ; P<0.001$ ), the rates of feed intake 749 and $666 \mathrm{~g} / \mathrm{d}$ (SED 21; $P<0.001$ ) and the feed conversion efficiencies (FCE) 0.517 and 0.891 (SED 0.019, $P<0.001)$. Female pigs in both treatments appeared to have a higher rate of feed intake than males, but the difference was not significant. The lower efficiency on the feed with the lower protein content $(\mathrm{L})$ reflects an increase in the lipid content of the gain of the pigs on this feed.

The feed intakes and live-weight gains for each day of the $6 \mathrm{~d}$ period subsequent to $16 \mathrm{~kg}$ live weight are illustrated in Figs. 1 and 2 respectively. The mean values for the $3 \mathrm{~d}$ on feed $\mathrm{L}$ and the $3 \mathrm{~d}$ on feed $\mathrm{H}$ are given in Table 2 . The values were analysed as a split-plot design, with pigs as main plots and days as sub-plots. For the pigs previously given feed $\mathrm{L}$, the mean live-weight gain on the days when feed $\mathrm{H}$ was given was 1.85 times that when feed $\mathrm{L}$ was given $(P<0.001)$ with no appreciable effect on feed intake. For the pigs previously 
(a)

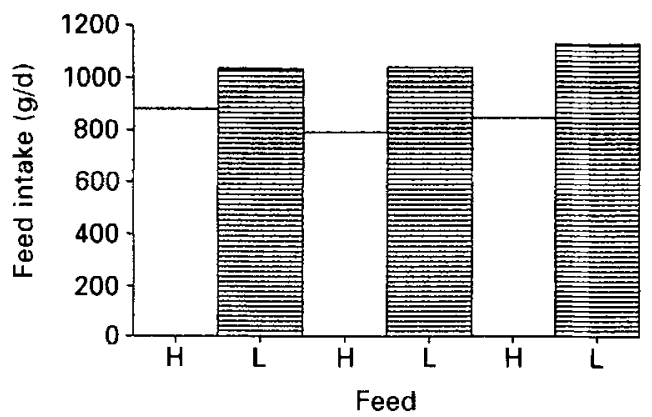

(b)

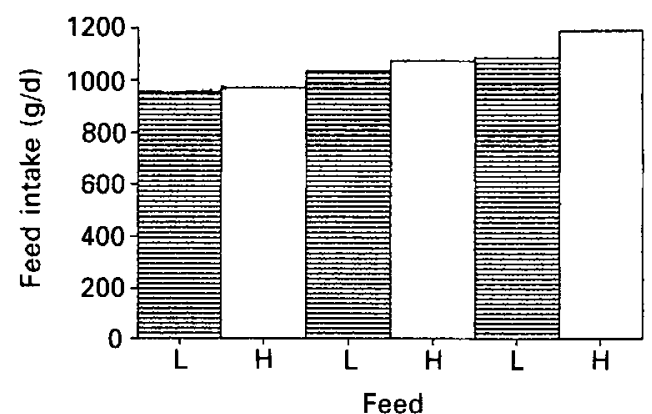

Fig. 1. The feed intakes for each of the days when feed $L$ 圈 or feed $H \square$ was given to pigs previously fed on $\mathrm{H}(a)$ and pigs previously fed on $\mathrm{L}(b)$. Values are the means for feed intake of twenty pigs.

(a)

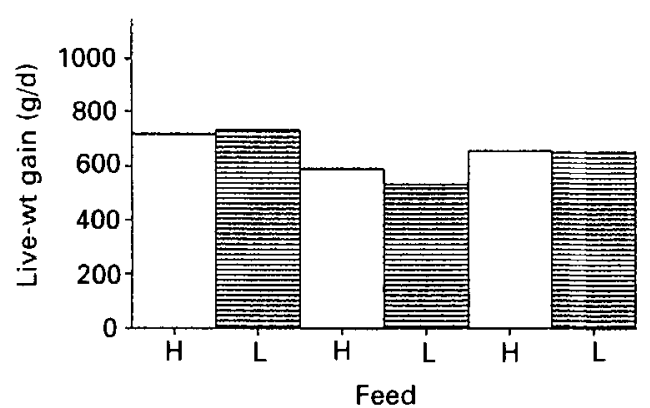

(b)

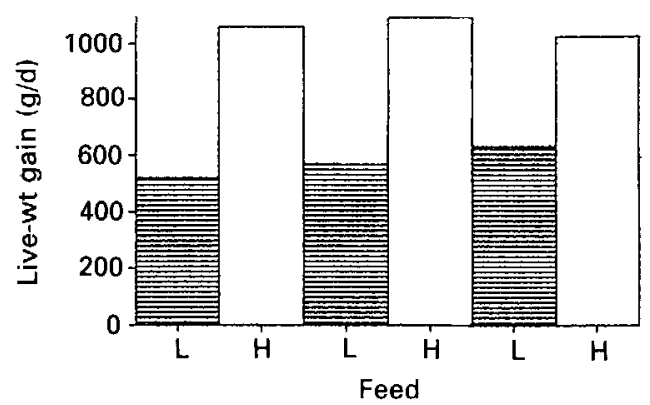

Fig. 2. The live-weight gains for each of the days when feed $\mathrm{L}$ 圆 or feed $\mathrm{H} \square$ was given to pigs previously fed on $\mathrm{H}(a)$ and pigs previously fed on $\mathrm{L}(b)$. Values are the means for live-weight gain of twenty pigs.

Table 2. The mean (averaged over $3 d$ ) live-weight gain, feed intake and efficiency of feed use by pigs given feeds $L$ or $H$ on successive days*

\begin{tabular}{|c|c|c|c|c|}
\hline Previous feeding & Feed given & Gain $(g / d)$ & $\begin{array}{l}\text { Feed intake } \\
\qquad(\mathrm{g} / \mathrm{d})\end{array}$ & $\begin{array}{c}\text { Feed conversion } \\
\text { efficiency } \\
\text { (g gain } / g \text { feed intake) }\end{array}$ \\
\hline \multirow[t]{3}{*}{$\mathrm{L}(n 20)$} & & & & \\
\hline & $\mathrm{H}$ & $1061^{a}$ & $1078^{a}$ & $0.983^{\mathrm{a}}$ \\
\hline & $\mathbf{L}$ & $575^{b}$ & $1027^{a}$ & $0 \cdot 560^{\mathrm{b}}$ \\
\hline \multirow[t]{4}{*}{$\mathrm{H}(n 20)$} & & & & \\
\hline & $\mathrm{H}$ & $655^{b}$ & $844^{b}$ & $0.755^{\mathrm{e}}$ \\
\hline & L & $610^{\mathrm{b}}$ & $1071^{\mathrm{a}}$ & $0.580^{\mathrm{b}}$ \\
\hline & SED & 43 & 30 & 0.039 \\
\hline
\end{tabular}

a.b.e Values in the same columns with different superscript letters were significantly different $(P<0.001)$, as assessed by a paired $t$ test.

* For details of feed compositions, see Table 1. 
fed on $\mathrm{H}$ the mean live-weight gain was only 1.08 times as great, but the effect on intake was significant $(P<0.001)$, with consumption $231 \mathrm{~g} / \mathrm{d}$ more on feed $\mathrm{L}$ than $\mathrm{H}$. Thus, the interaction between the feed given previously and the feed given for the $3 \mathrm{~d}$ of the subsequent $6 \mathrm{~d}$ period was highly significant for both live-weight gain $(P<0.001)$ and intake $(P<0 \cdot 001)$. Interactions with sex were not significant.

\section{DISCUSSION}

The increased intake on $\mathrm{L}$ compared with $\mathrm{H}$ of the pigs previously given $\mathrm{H}$ is consistent with the idea that pigs attempt to control their protein intake in the short run. Although there are apparently no other comparable experiments, it has been suggested that rats are able to detect changes in the protein content of their diet within $4 \mathrm{~h}$ (Harper, 1974) and hens are able to regulate their protein intake on a $12 \mathrm{~h}$ basis (Chah \& Moran, 1985). The absence of a similar difference in the intakes of pigs previously fed on $\mathrm{L}$, which arose because intake on feed $\mathrm{H}$ increased up to the intake on feed $\mathrm{L}$, can be accounted for by the growth rates of the animals on these treatments. For these pigs, which, following feeding on L, can be presumed to have depleted protein stores (Wallace, 1959; Tullis, 1981), daily live-weight gain was dramatically increased when feed $\mathrm{H}$ was given. Such increased gains have been attributed to a repletion of previously depleted labile protein reserves (Holt et al. 1962; Burton et al. 1974). These protein reserves are likely to be in the skeletal muscles, skin and feed-processing organs, since increased rates of protein synthesis were observed in these sites during re-alimentation following a period of feeding on a protein-deficient feed or a constraint feeding regimen (Millward et al. 1973; Ashley, 1985).

Short-term changes in live-weight can reflect changes in the weight of gut contents. For the pigs previously given $\mathrm{L}$ the intakes of feeds $\mathrm{L}$ and $\mathrm{H}$ were similar and the observed difference in gain is most unlikely to have reflected changes in gut-fill. This conclusion is supported by the feed efficiency values, calculated using the measured gains, which, at 0.56 for feed $\mathrm{L}$ and 0.98 for feed $\mathrm{H}$, were in good agreement with the values for these feeds when fed continually in the first part of the experiment of 0.52 and 0.89 respectively.

For the pigs previously fed $\mathrm{H}$ intake was 1.27 times higher when feed $\mathrm{L}$ rather than feed $\mathbf{H}$ was given. This difference in intake could have had the effect of confounding differences in empty body-gain with changes in gut-fill. If, for example, an extra $1 \mathrm{~g}$ feed intake/d led to an extra $0.35 \mathrm{~g}$ of gut-fill (a reasonable assumption for highly digestible feeds such as $\mathrm{L}$ and $H$ ) then the gain on $L$ should be reduced by 0.35 times the difference in feed intake and that on $\mathrm{H}$ should be increased by the same amount. The gains, adjusted for differences in presumed gut-fill in this way, become 531 and $734 \mathrm{~g} / \mathrm{d}$ for $\mathrm{L}$ and $\mathrm{H}$ respectively and the efficiencies 0.50 and 0.87 respectively. These adjusted efficiencies are in line with those expected from those measured in pigs on the two feeds in the 9-16 kg live-weight interval.

The rapid changes in intake and growth rate of the size seen here imply that the rate of metabolism of young pigs is extremely flexible, with a rapid rate of response to a change in the protein content of their feed. Such rapid response allows the protein eaten to be effectively used for growth.

I. K. was in receipt of a scholarship from the State Scholarship Foundation of the Hellenic Republic and the University of Edinburgh. The financial support of BOCM Silcock for the experimental part of this work is greatly acknowledged.

\section{REFERENCES}

Ashley, D. V. M. (1985). Factors affecting the selection of protein and carbohydrate from a dietary choice. Nutrition Research 5, 555-571. 
Burton, J. H., Anderson, M. \& Reid, J. M. (1974). Inter-relationships among energy input, body size, age and body composition in sheep. British Journal of Nutrition 32, 515-527.

Chah, C. C. \& Moran, E. T. (1985). Egg characteristics of high performance hens at the end of lay when given cafeteria access to energy, protein and calcium. Poultry Science 64, 1696-1712.

Harper, A. E. (1974). Amino acid excess. In Nutrients in Processed Feeds - Proteins, pp. $49-59$ (P. L. White and D. C. Fletcher, editors). Acton, Massachusetts: Publishing Sciences Group.

Henry, Y. (1985). Dietary factors involved in feed intake regulation in growing pigs: a review. Livestock Production Science 12, 339-354.

Holt, L. E., Halac, E. \& Kajdi, C. N. (1962). The concepts of protein stores and its implications in diet. Journal of the American Medical Association 181, 699-705.

Kirschgessner, M., Gerum, J. \& Roth-Maier, A. (1978). Körperzusammensetzung und Nahrstoffansatz 3-5 Wochen alter Broiler bei unterschiedlicher Energie - und Eiweiss Versorgung. Archiv für Geflügelkunde 42, $62-69$.

Kyriazakis, I. (1989). Growth, feed intake and diet selection in pigs: theory and experiments. PhD Thesis, University of Edinburgh.

Millward, D. J., Garlick, P. J., James, W.P. T., Nnanyelugo, D. O. \& Ryat, J. C. (1973). Relationships between protein synthesis and RNA content in skeletal muscle. Nature 241, 204-205.

Ranhorta, G. S. \& Jordan, R. M. (1966). Protein and energy requirements of lambs weaned at 68 weeks of age as determined by growth and digestive studies. Journal of Animal Science 25, 630-635.

Stamataris, C., Emmans, G. C., Hillyer, G. M. \& Whittemore, C. T. (1986). Fat young pigs: their performance and body composition on feeds with different nutrients: energy ratios. Animal Production 42, 437.

Tullis, J. B. (1981). Protein growth in pigs. PhD Thesis, University of Edinburgh.

Vaughan, O. W., Filer, L. J. \& Churella, H. (1962). Influence of prior dietary protein levels on resistance to the stress of protein depletion. Pediatrics 48, 1118-1120.

Wallace, W. M. (1959). Nitrogen content of the body and its relation to retention and loss of nitrogen. Federal Proceedings 19, 1125-1130.

Waterlow, J. C. \& Stephen, J. M. L. (1967). The measurement of total lysine turnover in the rat by intravenous infusion of $\mathrm{L}-\left[\mathrm{U}^{-14}{ }^{14} \mathrm{C}\right] \mathrm{ysine}$. Clinical Science 33, $489 \cdots 506$. 